\title{
Effect of gastrin on liver regeneration after partial hepatectomy in rats
}

\author{
T N Rasmussen, P E Jørgensen, T Almdal, S S Poulsen, P S Olsen
}

\begin{abstract}
Gastrin has been shown to be an important trophic hormone for the mucosa of the stomach and the proximal intestine. In the present study the effect of gastrin on liver regeneration after partial hepatectomy in rats was investigated. After partial hepatectomy a significant rise in the concentration of gastrin in portal venous blood was found six, 12 , and 18 hours after $70 \%$ hepatectomy. The effect of changes in the endogenous gastrin concentration on the liver regeneration was investigated in rats subjected to antrectomy or to fundectomy. Partial hepatectomy was done three weeks after the primary surgery. We found antrectomy to decrease liver regeneration, whereas fundectomy had no effect. Administration of pentagastrin $300 \mu \mathrm{g} / \mathrm{kg} \mathrm{sc}$ three times daily for two and four days after partial hepatectomy significantly increased the rate of liver regeneration compared with controls. This study suggests that gastrin has a hepatotrophic effect. Whether this effect is caused by a direct action of gastrin on the hepatocytes or it is an indirect effect mediated by for instance insulin, glucagon or epidermal growth factor has to be further investigated.
\end{abstract}

In rats partial hepatectomy, with removal of approximately $70 \%$ of the liver, induces a rapid induction of cell proliferation in the remaining hepatic tissue.' The increase in liver DNA synthesis after partial hepatectomy is initiated after a latent period of 10-14 hours. ${ }^{2}$ Within 1014 days the liver has regained its original size ${ }^{3}$ and the regenerative process is terminated abruptly. Experiments in partially hepatectomised rats have shown that removal of portal splanchnic organs, or diversion of portal blood supply delay liver regeneration. ${ }^{46}$ The hepatotrophic factors in portal venous blood may comprise hormones, regulatory peptides, and metabolites. ${ }^{7}$ Insulin and glucacon are important hepatotrophic factors. ${ }^{8}$ Epidermal growth factor also seems to be involved. ${ }^{910}$ One study has suggested that gastrin might also be a hepatotrophic factor, ${ }^{11}$ and increased concentration of gastrin occurs in patients with liver failure. ${ }^{12}$

Gastrin is mainly produced in the antral portion of the stomach. ${ }^{13}$ The peptide is a physiological stimulator of gastric acid secretion and has a trophic effect on parts of the gastrointestinal tract. ${ }^{1+18}$

The purpose of this study was to evaluate the role of gastrin on liver regeneration after partial hepatectomy in rats. The concentration of gastrin in portal venous blood after partial hepatectomy was measured and the effect of chronic endogenous hypo- and hypergastrinaemia as well as administration of pentagastrin on liverweight and DNA content was determined.

\section{Methods}

EXPERIMENTAL PROCEDURE

The studies were made on male Wistar rats weighing 300-350 g. The rats were allowed free access to food and water.

Partial hepatectomy was performed according to the method of Higgins ${ }^{3}$ by removal of the median and left lateral lobes (approximately 70\% of the liver). The rats were anaesthetised by intraperitoneal injection of $50 \mathrm{mg} / \mathrm{kg}$ methohexital (Brietal ${ }^{\circledR}$, Lilly, USA).

The effect of partial hepatectomy on the level of gastrin in portal venous blood was investigated in rats in groups of eight. Controls in groups of eight were sham-operated. All rats had blood drawn from the portal vein after $6,12,18,24,36$, 72 , and 120 hours, whereafter the rats were killed and the total body weight and the weight of the liver remnant was determined.

The effect of changes in the endogenous gastrin level on liver regeneration after partial hepatectomy was investigated in antrectomised and fundectomised rats. Ten rats underwent antrectomy and nine rats fundectomy as described elsewhere. ${ }^{18}$ Controls were sham operated. The rats were fasted 24 hours after surgery, but had free access to water. Three weeks after gastric surgery all rats had a blood sample taken from the inferior vena cava for determination of gastrin, and a $70 \%$ partial hepatectomy was performed, Ninety six hours later another blood sample was taken from the inferior vena cava for determination of gastrin, the rats were killed and the total body weight and the weight of the liver remnant was determined. Liver specimens were removed for determination of DNA.

The effect of pentagastrin (Peptavlon ${ }^{\circledR}, \mathrm{ICI}$, England) on liver regeneration after partial hepatectomy was investigated in rats. After partial hepatectomy 18 rats received pentagastrin $300 \mu \mathrm{g} / \mathrm{kg} \mathrm{sc}$ three times daily. Eight rats were killed after 48 hours and 10 rats after 96 hours of treatment. Two groups of eight sham operated rats served as controls and received saline. All rats had total body weight and weight of the liver remnant determined. Liver specimens were removed for later determination of DNA.

LABORATORY ANALYSES

Serum gastrin concentration was measured radioimmunochemically. Antiserum 2604 is highly specific for gastrin and binds the three 
larger molecular forms of gastrin with almost equimolar potency, ${ }^{19}$ it crossreacts less than $0 \cdot 1 \%$ with cholecystokinin and does not react with other peptides. ${ }^{20}$ Synthetic human gastrin I was used for monoiodination and standard. The reliability of the assay has been described elsewhere, ${ }^{21}$ as well as the accuracy of the assay in measuring serum from the rat. ${ }^{2}$

The DNA content of the liver was measured as described elsewhere. ${ }^{23}$

\section{STATISTICAL ANALYSIS}

For statistical evaluation the Mann-Whitney's test was used. Analysis of variance was made by Kruskal-Wallis test. Values of $\mathrm{p}<0.05$ were considered significant. All results are given as medians and total ranges.

\section{Results}

The concentration of gastrin in portal venous blood and the changes in liver weight after partial hepatectomy are shown in the Figure. A significant rise in serum gastrin concentration was found 6,12 , and 18 hours after partial hepatectomy compared with controls.

The effect of antrectomy and fundectomy on the endogenous gastrin level is shown in Table $\mathrm{I}$. Antrectomy decreases the serum concentration of gastrin by approximately $50 \%$, whereas fundectomy increases the concentration approximately four times. No significant difference in serum gastrin concentration was found in each single group before and four days after partial hepatectomy. Fundectomy had no significant effect on liver regeneration after partial hepatectomy, whereas antrectomy reduced liver regeneration significantly compared with controls (Table II).

Administration of pentagastrin $300 \mu \mathrm{g} / \mathrm{kg} \mathrm{sc}$ three times daily, increased the DNA content of the liver remnant significantly 48 and 96 hours after partial hepatectomy compared with controls (Table III).

TABLE I Serum gastrin concentration three weeks after antrectomy or fundectomy and 96 hours after $70 \%$ partial hepatectomv in rats

\begin{tabular}{|c|c|c|c|c|}
\hline Treatment 3 weeks & $\begin{array}{l}\text { gastrin } \\
\text { pmol/l }\end{array}$ & Treatment & 96 hours & $\begin{array}{l}\text { gastrin } \\
\text { pmol/l }\end{array}$ \\
\hline $\begin{array}{lr}\text { Sham-operation } & 7 \\
\text { Antrectomy } & 2 \\
\text { Fundectomy } & 29\end{array}$ & $\begin{array}{l}(44-162) \\
(13-70)^{\star} \\
(140-482) \dagger\end{array}$ & $\begin{array}{l}\text { hepatectom } \\
\text { hepatectom } \\
\text { hepatectom }\end{array}$ & $\begin{array}{r}74 \\
35 \\
360\end{array}$ & $\begin{array}{l}(2+108) \\
(19-110) \\
(22+-498) \dagger\end{array}$ \\
\hline
\end{tabular}

Results are given as medians and total ranges.

${ }^{\star} \mathrm{p}<0.001$ compared with controls; $+\mathrm{p}<0.001$ compared with controls.

TABLE II Effect of antrectomy and fundectomy on liver regeneration after $70 \%$ partial hepatectomy in rats

\begin{tabular}{lcl}
\hline Treatment & $n$ & mgliver DNA/100 g bw \\
\hline Sham operation +hepatectomy & 10 & $6 \cdot 75(5 \cdot 16-7 \cdot 94)$ \\
Antrectomy +hepatectomy & 10 & $4.93(4 \cdot 07-5 \cdot 52)^{\star}$ \\
Fundectomy + hepatectomy & 9 & $6 \cdot 15(4 \cdot 43-7 \cdot 87)$
\end{tabular}

Results are given as medians and total ranges. ${ }^{\star} \mathrm{p}<0 \cdot 005$ compared with controls. All the rates were subjected to $70 \%$ partial hepatectomy three weeks after gastric surgery. All the rats were killed 96 hours after partial hepatectomy and the total body weight determined.

TABLE III Effect of pentagastrin on liver regeneration after $70 \%$ partial hepatectomy in rats

\begin{tabular}{llrl}
\hline Treatment & $\begin{array}{l}\text { Treatment } \\
(h)\end{array}$ & $n$ & mg liver DNA/loo g bw \\
\hline Saline & 48 & 8 & $3 \cdot 72(3 \cdot 15-4 \cdot 30)$ \\
Pentagastrin & 48 & 8 & $5 \cdot 60(4 \cdot 45-6 \cdot 14)^{\star}$ \\
Saline & 96 & 8 & $6 \cdot 39(5 \cdot 60-6 \cdot 52)$ \\
Pentagastrin & 96 & 10 & $9 \cdot 95(7 \cdot 48-14 \cdot 26) \dagger$ \\
\hline
\end{tabular}

Results are given as medians and total ranges. ${ }^{\star} \mathrm{p}<0.005$ and $t p<0.005$ compared with controls. Pentagastrin was administered tp $<0.005$ compared with controls. Pentagastrin was administered in a dose of $300 \mathrm{\mu g} / \mathrm{kg}$ se three times daily. Controls received saline three times daily. All rats were killed at the end of treatment and total body weight and weight, and DNA content, of the liver remnant was determined.

\section{Discussion}

During the last years evidence has accumulated

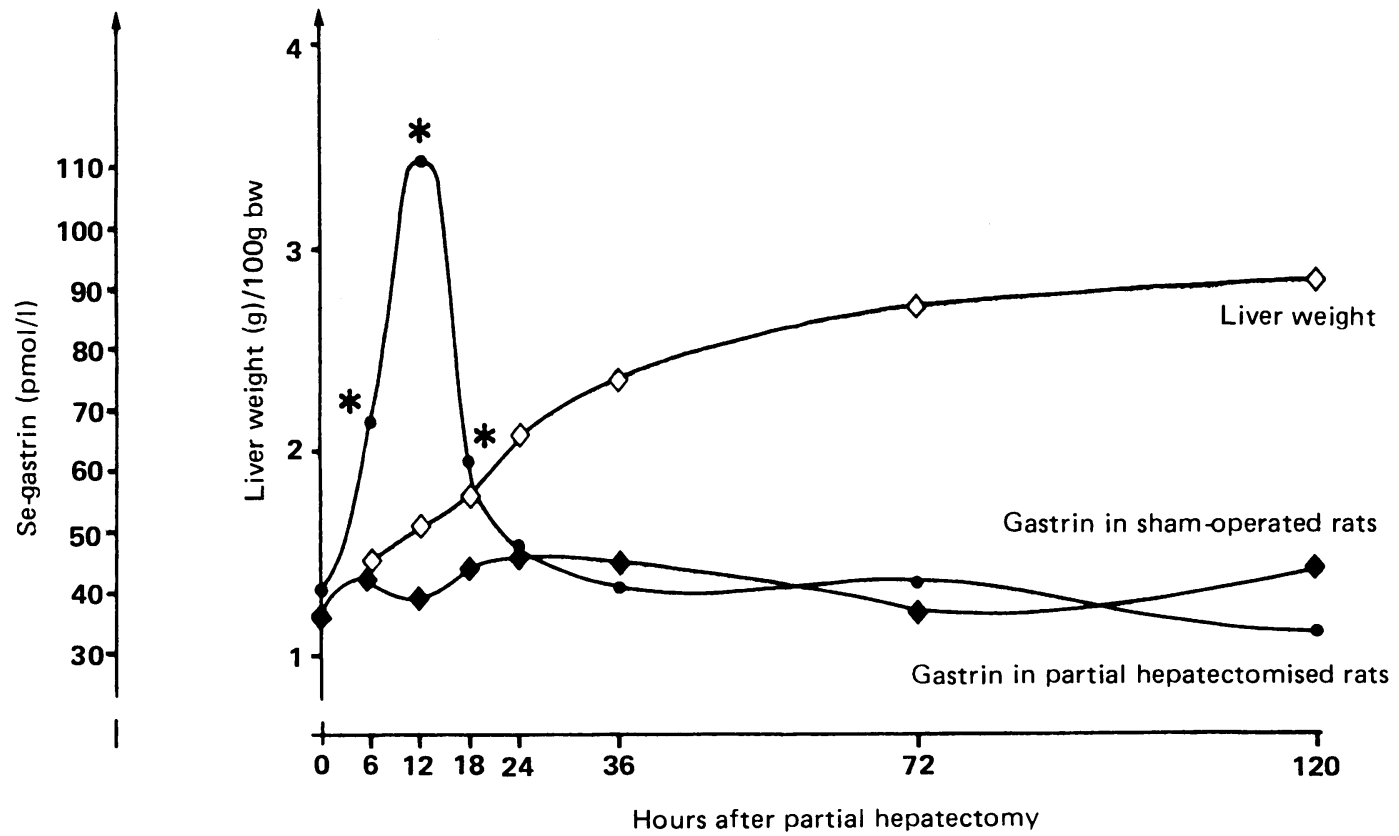

Figure: Concentration of gastrin in portal venous blood and change in liver weight after $70 \%$ partial hepatectomy in rats. The values shown are the medians. ${ }^{\star} p<0.05$ compared with sham-operated controls. 
that humoral factors in portal venous blood are involved in stimulation of liver regeneration after partial hepatectomy in rats. ${ }^{7}$ Insulin, glucagon and epidermal growth factor seems to belong to a group of substances that stimulate liver regeneration. ${ }^{8-10}$

Gastrin has at least two physiological actions: it stimulates gastric acid secretion and has a trophic effect on the gastrointestinal tract. Gastrin stimulates DNA, RNA, and protein synthesis of the mucosa long the entire length of the gut with the exception of the oesophagus and antrum. ${ }^{24}$

In the present study a possible role of gastrin in stimulation of liver regeneration after partial hepatectomy in rats was demonstrated. The concentration of gastrin in portal venous blood increased 6, 12, and 18 hours after the operation. Whether this is necessary to stimulate liver regeneration or it represents a secondary change in the metabolism of gastrin is unknown. Partial hepatectomised rats develop a characteristic change in the level of several regulatory peptides such as insulin, glucagon, and thyroid hormones, however, substances that are believed to be involved in the stimulation of liver regeneration. These hormonal changes occur rapidly after liver resection, but several hours before the DNA replication starts. ${ }^{82526}$ An identical delay has been observed between administration of gastrin and increase in thymidine uptake in mucosa of the intestinal mucosa. ${ }^{17}$ The increased level of gastrin in portal venous blood might participate in the initiation of the regenerative process in the liver after partial resection.

In order to show that gastrin physiologically influences liver regeneration in rats one must show the effect of the endogenous hormone. The level of endogenous gastrin can be manipulated by removal of the rat antrum and by fundectomy. ${ }^{18}$ We found antrectomy to decrease the level of gastrin by a factor of 2 , while the concentration of gastrin after fundectomy increased four to five times. In antrectomised rats liver regeneration, measured by DNA content, decreased significantly, whereas fundectomy had no effect. Antrectomy has previously been shown to induce atrophy of the colonic, duodenal and oxyntic gland mucosa, whereas the weight of the intact liver was unchanged. ${ }^{27}$ Oscarson $e t a l^{18}$ found fundectomy to increase the level of circulating gastrin, but changes in the height and weight of the gastrointestinal mucosa could not be identified. In rats, made chronic hypergastrinaemic by implanting the gastric antrum into the side of the colon, an increased weight of the intact liver was found." The effect of antrectomy in our study suggests that the increase in circulating gastrin after partial hepatectomy is necessary to accelerate liver regeneration. The increase in endogenous serum gastrin concentration after fundectomy is probably too low to accelerate the spontaneous liver regeneration compared to the effect of pentagastrin. One possibility is that antrectomy and fundectomy influence the secretion of various gastrins with different trophic potency ${ }^{28}$ or other hepatotrophic factors such as insulin and epidermal growth factor.
Pentagastrin has a trophic effect on the gut similar to gastrin 17 and gastrin $34 .{ }^{28}$ In previous studies the effect of pentagastrin on liver growth has only been investigated on intact livers. Pentagastrin given for 24 hours as well as seven days had no effect on liver growth. ${ }^{27}{ }^{29} \mathrm{We}$ found a significant effect of pentagastrin on liver regeneration after partial hepatectomy 48 and 96 hours after the operation. The different effect of pentagastrin on the intact and partial hepatectomised liver could be caused by the fact that the growth stimulus elicited by pentagastrin alone is too small to be detected in the intact liver. In the partial hepatectomised rat several other hepatotrophic factors are activated and can act together with pentagastrin such as insulin and glucagon.

In conclusion this study suggests that gastrin is involved in stimulation of liver regeneration after partial hepatectomy in rats. Whether this effect is the result of a direct effect of gastrin on the liver cells or it is an indirect effect mediated through other hepatrophic factors is still unknown.

The skilful assistance of technician B Fich is gratefully acknowledged. This study was supported by Lily Benthine Lund Foundation.

1 Bucher NLR, Swaffield MN. The rate of incorporation of labeled thymine into deoxyribonucleic acid of regenerating rat liver in relation to amount of liver excised. Cancer Res 1964; 24: 1611-25.

2 Bucher NLR, Swaffield MN, Di Troia JF. The influence of age upon the incorporation of thymidine-2- $\mathrm{C}^{14}$, into the DNA of regenerating rat liver. Cancer Res 1964; 24: 509-12.

3 Higgins GM, Anderson RM. Experimental pathology of the liver. Arch Pathol 1931; 12: 186-202.

4 Starzl TE, Porter KA, Francavilla JA, Benichon J, Putnam $\mathrm{CW}$. A hundred years of the hepatotrophic controversy. Cib Foundation Symposium 1978; 55: 111-38.

5 Bucher NLR, Swaffield MN. Regeneration of liver in rats in the absence of portal splanchnic organs and a portal blood the absence of portal splanchnic organ

6 Starzl TE, Francavilla A, Halgrimson CG, et al. The origin, hormonal nature, and action of hepatrophic substances in portal venous blood. Surg Gynecol Obstet 1973;137: 179-99.

7 Leffert HL, Koch KS, Moran T, Rubalcava B. Hormonal control of rat liver regeneration. Gastroenterology 1979; 76: $1470-82$.

8 Bucher NLR, Patel U, Cohen S. Hormonal factors concerned with liver regeneration. In: Ciba Foundation Symposium 55 (new series). Hepatotrophic factors. Elsevier North Holland 1978: 95-111.

9 Olsen PS, Boesby S, Kirkegaard P, Therkelsen K, Poulsen SS Almdal T, Nexø E. Influence of epidermal growth factor on liver regeneration after partial hepatectomy in rats. Hepatology 1988; 8: 992-6.

10 Raper SE, Burwen SJ, Baker ME, Jones AL. Translocation of epidermal growth factor to the hepatocyte nucleus during rat liver regeneration. Gastroenterology 1987; 92: 1243-50.

11 MacGregor IL, Lawrence WW. Chronic hypergastrinemia produces hypertrophy of the liver and intestine in rats. Surg Forum 1977; 27: 411-3.

12 Sullivan SN, Chase RA, Christofides ND, Bloom SR, Williams R. The gut hormone profile of fulminant hepatic Williams R. The gut hormone profile of fulm
failure. Am $\mathcal{f}$ Gastroenterol 1981;76: 338-41.

13 Walsh JH, Grossman MI. Gastrin. N Engl f Med 1975; 292 $1324-34$.

14 Johnson LR, Lichtenberger LM, Copeland EM. Action of gastrin on gastrointestinal structure and function. Gastroenterology $1975 ; 68$ : 1184-92

15 Barrowman JA. The trophic action of gastrointestinal hormones. Digestion 1975; 12: 92-104.

16 Reber HA, Johnson F, Deveney K, Montgomery C, Way LW Trophic effect of gastrin on the exocrine pancreas in rats. 7 Surg Res 1977; 22: 554-60.

17 Johnson LR, Guthrie PD. Mucosal DNA synthesis: A short term index of the trophic action of gastrin. Gastroenterology 1974; 67: 453-9.

18 Oscarson J, Haakonson R, Liedberg G, Lundquist G, Sundler $\mathrm{F}$, Thorell J. Variated serum gastrin concentration: Trophic effect on the gastrointestinal tract of the rat. Acta Physiol effect on the gastrointestinal tract
Scand $1979 ; 107$ (suppl 475): 1-27.

19 Rehfeld JF. Disturbed islet-cell function related to endogenous gastrin release. Studies on insulin secretion and glucose tolerance in pernicious anemia. 7 Clin Invest 1978 58: 41-9.

20 Rehfeld JF, Stadil F, Rubin B. Production and evaluation of antibodies for the radioimmunoassay of gastrin. Scand $\mathcal{F}$ Cli Lab Invest 1972; 30: 221-32.

21 Stadil F, Rehfeld JF. Determination of gastrin in serum. An 
evaluation of the reliability of a radioimmunoassay. Scand 7 Gastroenterol 1973; 8: 101-12.

22 Håkanson R, Kroensen JH, Liedberg G, Oscarson J, Rehfeld $\mathrm{JF}$, Stadil F. Correlation between serum gastrin concentration and rat stomach histidine decarboxylase activity. F Physiol (Lond) 174; 243: 483-98.

23 Monro AN, Fleck $A$. The determination of nucleic acids. Methods Biochem Anal 1966; 14: 113-76.

24 Enochs MR, Johnson LR. Trophic effect of gastrointestinal hormones: physiological implications. Fed Proc 1977; 36: 1942-7.

25 Bucher NLR, Swaffield MN. Regulation of hepatic regeneration by synergistic action of insulin and glucagon. Proc Natl
Acad Sci USA 1975; 72: 1157-60.

26 Leffert HL, Alexander NM. Thyroid hormone metabolism during liver regeneration in adult rats. Endocrinology 1976 ; 98: $1205-11$

27 Dembinski AB, Johnson LR. Growth of pancreas and gastrointestinal mucosa in antrectomized and gastrin-treated rats Endocrinology 1979; 105: 769-73.

28 Johnson LR, Guthrie PD. Stimulation of DNA synthesis by big and little gastrin (G-34 and G-17). Gastroenterologv 1976 71: 599-602.

29 Chandler AM, Johnson LR. Pentagastrin-stimulated incorporation of ${ }^{14} \mathrm{C}$-Orotic acid into RNA of gastric and duodenal mucosa. Proc Soc Exp Biol Med 1972; 141: 110-3. 